\title{
Association of ATP1A1 gene polymorphism with thermotolerance in Tharparkar and Vrindavani cattle
}

Neeraj Kashyap ${ }^{1}$, Pushpendra Kumar ${ }^{1}$, Bharti Deshmukh², Sandip Bhat ${ }^{1}$, Amit Kumar ${ }^{1}$, Anuj Chauhan ${ }^{1}$, Bharat Bhushan ${ }^{1}$, Gyanendra Singh ${ }^{3}$ and Deepak Sharma

1. Division of Animal Genetics, Indian Veterinary Research Institute, Izatnagar, Bareilly, Uttar Pradesh, India;

2. Department of Animal Genetics and Breeding, Govind Ballabh Pant University of Agriculture and Technology, Pantnagar, Uttarakhand, India; 3. Division of Physiology and Climatology, Indian Veterinary Research Institute, Izatnagar, Bareilly, Uttar Pradesh, India.

Corresponding author: Neeraj Kashyap, e-mail: neeraj.vety@gmail.com,

PK: pushpendra64@gmail.com, BD: bharti.vet@gmail.com, SB: sandipivri@gmail.com, AK: vetamitchandan07@gmail.com,AC: anuj_vet99@rediffmail.com, BB: bbhushan_ivri2003@yahoo.co.in, GS: gyanendra@ivri.res.in, DS: ds7758@yahoo.co.in

Received: 19-03-2015, Revised: 13-06-2015, Accepted: 20-06-2015, Published Online: 21-07-2015

doi: 10.14202/vetworld.2015.892-897 How to cite this article: Kashyap N, Kumar $P$, Deshmukh $B$, Bhat $S$, Kumar $A$, Chauhan A, Bhushan B, Singh G, Sharma D (2015) Association of ATP1A1 gene polymorphism with thermo tolerance in Tharparkar and Vrindavani cattle, Veterinary World 8(7): 892-897.

\begin{abstract}
Aim: One of the major biochemical aspects of thermoregulation is equilibrium of ion gradient across biological membranes. $\mathrm{Na}^{+} / \mathrm{K}^{+}$-ATPase, a member of P type-ATPase family, is a major contributor to the mechanism that actively controls crossmembrane ion gradient. Thus, we examined ATPlAl gene that encodes alpha- 1 chain of $\mathrm{Na}^{+} / \mathrm{K}^{+}$-ATPase, for genetic polymorphisms.

Materials and Methods: A total of 100 Vrindavani (composite cross strain of Hariana x Holstein-Friesian/Brown Swiss/ Jersey) and 64 Tharparkar (indigenous) cattle were screened for genetic polymorphism in ATP1A1 gene, using polymerase chain reaction single-strand conformation polymorphism and DNA sequencing. For association studies, rectal temperature (RT) and respiration rate (RR) of all animals were recorded twice daily for 3 seasons.

Results: A SNP (C2789A) was identified in exon 17 of ATP1A1 gene. Three genotypes namely CC, CA, and AA were observed in both, Vrindavani and Tharparkar cattle. The gene frequencies in Tharparkar and Vrindavani for allele A were 0.51 and 0.48 , and for allele $\mathrm{C}$ were 0.49 and 0.52 , respectively, which remained at intermediate range. Association study of genotypes with RT and RR in both cattle population revealed that the animals with genotype CC exhibited significantly lower RT and higher heat tolerance coefficient than CA and AA genotypes.
\end{abstract}

Conclusion: Differential thermoregulation between different genotypes of ATP1A1 gene indicate that the ATP1A1 gene could be potentially contributing to thermotolerance in both, Tharparkar, an indigenous breed and Vrindavani, a composite crossbred cattle.

Keywords: ATP1A1 gene, cattle, polymorphism, thermotolerance, Tharparkar, Vrindavani

\section{Introduction}

Heat production and heat loss have a delicate balance, which is maintained by certain thermoregulatory mechanisms in response to ambient temperature and humidity combinations. When the heat loss is overrun by heat gain, the homeostatic mechanism triggers the thermoregulatory response of animal to maintain the body temperature within normal range. During heat stress, increase in the core body temperature due to failure of homeostatic mechanism reduces productivity of the animals below their original genetic potential in growth [1], milk production [2-4], milk constituents, [5,6] and reproduction [7-10].

The genes that contribute to either heat production or heat loss mechanisms are related to the tolerance against heat; along with certain biochemical and molecular processes that protect against cell injury

Copyright: The authors. This article is an open access article licensed under the terms of the Creative Commons Attributin License (http:// creative commons.org/licenses/by/2.0) which permits unrestricted use, distribution and reproduction in any medium, provided the work is properly cited. caused by excessive heat accumulation. Many of the candidate genes responding to thermal stress have been identified using microarray assays or expression profiling [11]. Studies have been carried out to identify allelic variants in some genes that confer heat tolerance in cattle, such as slick hair gene [12], ATP1B2 gene [13], HSP70A1A [14,15], HSP90AB1 [16], etc. One of those genes is $A T P 1 A 1$, which encodes for the $\alpha 1$ chain of $\mathrm{Na}^{+} / \mathrm{K}^{+}$-ATPase that contains the catalytic unit of the enzyme. The $\mathrm{Na}^{+} / \mathrm{K}^{+}$-ATPase is a membrane bound active transport system responsible for maintaining the low internal $\mathrm{Na}^{+}$and high internal $\mathrm{K}^{+}$ across the plasma membrane that is typical to most animal cells. $\mathrm{Na}^{+} / \mathrm{K}^{+}$-ATPase alpha chain is expressed in all tissues predominantly in peripheral nerves and in erythrocytes [17]. The importance of $\mathrm{Na}^{+} / \mathrm{K}^{+}$-ATPase in basal metabolism can be highlighted by the fact that it consumes $19-28 \%$ of total ATP production in mammalian cells at rest, to actively transport $3 \mathrm{Na}^{+}$of and $2 \mathrm{~K}^{+}$into the cell [18].

$\mathrm{Na}^{+} / \mathrm{K}^{+}$-ATPase activity has also been reported to affect blood pressure regulation [19] and osmotic 
stress management in saline water fish [20]. Genetic variants of the ATP1Al gene have been suggested to be involved in the salt hypertension in Dahl rats [21]; feed intake in cattle [22]; and essential hypertension in humans [23], all of which may evidently affect heat production, heat loss, and water mineral balance. Further, Yang [24] found $\mathrm{Na}^{+} / \mathrm{K}^{+}$-ATPase activity to be associated with heat resistance ability with a high heritability of 0.53 in cattle. It has also been shown that certain genotypic variants of different $\mathrm{Na}^{+} /$ $\mathrm{K}^{+}$-ATPase subunits have different heat tolerance in cows [25-28]. A differential expression of ATP1A1 in different seasons [29] is also suggestive of the gene to have a certain part in animals' response to environmental attributes.

It has been established that Indian breeds of cattle are better able to regulate their body temperature in response to heat stress than the exotic breeds of cattle [30,31]. Further, increase in exotic blood level in crossbreds leads to depression of production potential during heat stress $[3,32]$. Tharparkar cattle have evolved in the hot arid western region of India and believed to have better thermotolerance, whereas Vrindavani strain has been developed by the composite cross of various taurine breeds with Hariana breed of cattle. Therefore, the present study was undertaken to study the polymorphism of ATPIAl gene and its association with thermoregulation in Tharparkar and Vrindavani cattle.

\section{Materials and Methods \\ Ethical approval}

The experiment was prior approved by the Animal Ethics Committee of the Institute constituted as per the article number 13 of the CPCSEA rules laid down by Government of India and conducted following the code of ethics for animal experimentation.

\section{Experimental animals}

A total of 164 adult female cattle, comprising 100 Vrindavani crossbred (Hariana $\times$ HolsteinFriesian/Brown Swiss/Jersey) and 64 Tharparkar were included under present investigation maintained at Cattle and Buffalo Farm, Indian Veterinary Research Institute, Izatnagar, Bareilly (UP), India. About $10 \mathrm{ml}$ of venous blood was collected from each animal under sterile conditions and genomic DNA was isolated by phenol: Chloroform extraction method [33].

\section{Genotyping}

A set of primers (forward 5'-ACAAACAAAAGGGTCACAACAT-3' and reverse 5'-CTTACCCTAGATCCTGGCTCAT-3') reported by Liu, et al. [26] was used for amplification of $301 \mathrm{bp}$ fragment of ATP1A1 gene spanning around exon 17. Reaction mixture of $25 \mu \mathrm{l}$ for polymerase chain reaction (PCR) was prepared containing $15.7 \mu \mathrm{l}$ of nuclease free water, $2.5 \mu \mathrm{l} \times 10$ Taq buffer, $2 \mu \mathrm{l}$ of $\mathrm{MgCl}_{2}(25 \mathrm{mM}), 1 \mu \mathrm{l}$ (50 ng) genomic DNA, $1 \mu \mathrm{l}$ of both forward and reverse primers $(10 \mathrm{pM} / \mu \mathrm{l})$ each,
$0.8 \mu \mathrm{l}$ of dNTPs mix $(10 \mathrm{mM})$, and $1 \mu \mathrm{l}$ of Taq dna polymerase $(1 \mathrm{U} / \mathrm{ml})$. The program for thermal cycling included an initial denaturation step at $95^{\circ} \mathrm{C}$ for $5 \mathrm{~min}$, followed by 30 cycles of denaturation at $95^{\circ} \mathrm{C}$ for $60 \mathrm{~s}$, annealing at $60^{\circ} \mathrm{C}$ for $45 \mathrm{~s}$, extension at $72^{\circ} \mathrm{C}$ for $60 \mathrm{~s}$, and final extension at $72^{\circ} \mathrm{C}$ for $10 \mathrm{~min}$.

The $5 \mu \mathrm{l}$ of the PCR products was added to $15 \mu \mathrm{l}$ formamide dye $(95 \% \mathrm{v} / \mathrm{v}$ Formamide, $4 \% \mathrm{v} / \mathrm{v} 0.5 \mathrm{M}$ Ethylenediaminetetraacetic acid [EDTA], $0.025 \% \mathrm{w} / \mathrm{v}$ bromophenol blue, and $0.025 \% \mathrm{w} / \mathrm{v}$ xylene cyanol) and mixed properly followed by denaturation at $95^{\circ} \mathrm{C}$ for $10 \mathrm{~min}$ then snap chilling on ice for $15 \mathrm{~min}$, to form different single stranded DNA confirmations. Resolution of genotypes was carried out by electrophoresis using $\times 1$ TBE (45 mM Tris-borate/mM EDTA) at $4^{\circ} \mathrm{C}$ on $12 \%$ polyacrylamide gel (acrylamide/bisacrylamide $49: 1, \mathrm{~V} / \mathrm{v}$ ) for $18 \mathrm{~h}$ at $130 \mathrm{~V}$. PCR-single strand conformation polymorphism (PCR-SSCP) banding patterns were detected by silver staining according to Bassam, et al. [34]. The representative samples of different PCR-SSCP patterns were purified with QIA quick ${ }^{\circledR}$ Gel extraction kit (QIAGEN), cloned in pGEM $^{\circledR}$-T easy vector (Promega), and sequenced by the Sanger's dideoxy chain termination sequencing method from both forward and reverse directions by primers for ATP1Al gene.

\section{Environmental and physiological parameters}

Daily mean temperature was taken as the average of maximum and minimum temperatures of the day, recorded over 3 consecutive days of each season, i.e., winter (January), spring (March), and summer (May). The temperature humidity index (THI) was derived from a combination of wet- and dry-bulb air temperatures recorded for each day and expressed as THI $=0.72\left(\mathrm{~T}_{\mathrm{W}}+\mathrm{T}_{\mathrm{D}}\right)+40.6[35]$ where, $\mathrm{T}_{\mathrm{w}}$ is wetbulb air temperature $\left(\right.$ in $^{\circ} \mathrm{C}$ ) and $\mathrm{T}_{\mathrm{D}}$ is dry-bulb air temperature $\left(\right.$ in $\left.^{\circ} \mathrm{C}\right)$.

Rectal temperature (RT) was measured in all animals twice daily, morning at 10:00 am, and afternoon at 2:00 pm, for 3 consecutive days in each season. During the same time, average respiration rate (ARR) was determined by monitoring flank movements of the animal for 1 min while resting. Heat tolerance coefficient (HTC) was calculated for each cow as an index of its heat tolerability. HTC and RR were measured in all 150 Vrindavani and 64 Tharparkar cows in all 3 test periods. Iberia heat tolerance test was used to determine HTC: HTC = 100-10 (ART-38.3) [36]; where, ART is the average of RT at 10:00 am and 3:00 pm of 3 consecutive days for each test period and 38.3 is the normal RT of cattle (in ${ }^{\circ} \mathrm{C}$ ).

\section{Statistical analysis}

The association of the polymorphism of the ATPlAl gene with thermoregulatory traits was analyzed using GLM procedure of SAS software package version 9.3, which uses the method of least squares to fit general linear models. The least squares mean of different RT (10 am, 2 pm, and average) and ARR 
were compared by model: $\mathrm{Y}_{\mathrm{ijkl}}=\mu+\mathrm{B}_{\mathrm{i}}+\mathrm{S}_{\mathrm{j}}+\mathrm{G}_{\mathrm{k}}+\mathrm{e}_{\mathrm{ijk} \mathrm{l}}$, where, $\mathrm{Y}_{\mathrm{ijkl}}$ is the observation of the trait; $\mathrm{m}$ is overall mean; $B_{i}$ is the fixed effect of $i^{\text {th }}$ breed; $S_{j}$ is the effect of $j^{\text {th }}$ season; $G_{k}$ is the fixed effect of $k^{\text {th }}$ genotype; and $\mathrm{e}_{\mathrm{ijkl}}$ is random error.

\section{Results and Discussion}

\section{Polymorphism in ATP1A1 gene}

A 301 bp fragment of ATP1A1 gene encompassing exon 17 was amplified successfully with the used pair of primers. 3 genotypes (AA, AC, and CC) and 2 alleles namely A and $\mathrm{C}$ were evident on PCR-SSCP by different banding patterns (Figure-1). The nucleotide sequencing and analysis of these genotypes revealed that a SNP (C>A) was located at 29140575 base of Bos taurus chromosome 3 corresponding to 2789 base of ATP1A1 mRNA (Figure-2). The identified SNP was a synonymous mutation. The sequences of allele $\mathrm{A}$ and $\mathrm{C}$ found in Tharparkar and Vrindavani were submitted to NCBI with accession number JX489364, JX489365, JX489366, and JX489367. The genotype frequencies for $\mathrm{AA}, \mathrm{AC}$, and $\mathrm{CC}$ genotypes were 0.24 , 0.47 , and 0.29 while $0.31,0.39$, and 0.30 in Vrindavani and Tharparkar, respectively. The gene frequencies for allele $A$ and $C$ were 0.51 and 0.49 and 0.52 and 0.48 in Vrindavani and Tharparkar, respectively. Frequency of heterozygotes was found much more than either the homozygotes in both cattle population. Though the frequencies of alleles did not vary much between Tharparkar and Vrindavani, they were found differing from that of the Chinese Holstein cattle where allele C was found most frequent (0.86) [26].

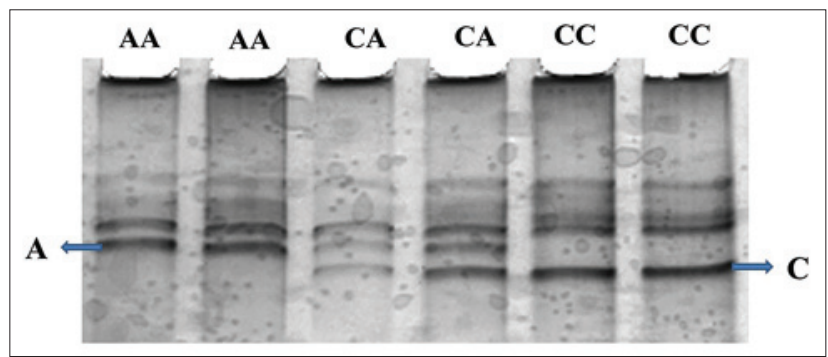

Figure-1: SSCP genotypes of amplified fragment covering exon 17 of $A T P 1 A 1$ gene.

\section{Environmental parameters}

For winter, spring, and summer, the average daily temperature $\left({ }^{\circ} \mathrm{C}\right)$ was $10.83,22.67$, and 33.16 , respectively, while RH (\%) was recorded to be 70, 41, and 33.33, respectively. McDowell, et al. [35] suggested that the THI could be used as a better indicator of thermal climatic conditions. The THI values were lowest for winter (52.72), followed by spring (68.25), and highest for summer (84.34). Considering threshold for heat stress on cattle at THI value of 72 [37], the THI values for test period of summer season exceeded the comfort zone of THI for dairy cattle, thus imposing heat stress on animals. However, the THI values for winter and spring were below the critical THI values and remained within the comfort zone for cattle.

\section{Thermoregulatory parameters}

In both cattle populations, the effect of genotypes was found statistically significant $(\mathrm{p} \leq 0.01)$ for 10 am RT (RT $\left.{ }_{\mathrm{M}}\right), 2$ pm RT (RT), average RT (ART), and HTC; while it was statistically non-significant for ARR. The CC genotype accounted for lowest values for $\mathrm{RT}_{\mathrm{M}}, \mathrm{RT}_{\mathrm{A}}, \mathrm{ART}$, and highest value for HTC while there was no significant difference between genotype AA and CA for any of these parameters. For ARR, the difference was not statistically significant between genotype $\mathrm{AA}, \mathrm{AC}$, and $\mathrm{CC}$ in Tharparkar; while in Vrindavani, genotype $\mathrm{CC}$ was statistically different $(\mathrm{p} \leq 0.01)$ and lower from genotype AA and CA (Table-1). The effect of season was found significant, with highest $\mathrm{RT}_{\mathrm{M}}, \mathrm{RT}_{\mathrm{A}}, \mathrm{ART}$ and $\mathrm{RR}$ but lowest HTC values in summer in both cattle populations (Table- 2).

The animals with genotype CC maintained the lowest ART followed by animals with genotype CA and AA in Tharparkar (Figure-3) as well as in Vrindavani (Figure-4) for each season. The consistency of the higher HTC in genotype CC through all seasons suggests probable differential heat production or heat loss between the genotypes. In the present study, higher thermotolerant effects of genotype $\mathrm{CC}$ in summer was in agreement to the findings of Liu, et al. [26] on Chinese Holstein cattle and extends their findings in zebu-taurine crossbreds and indigenous zebu cattle. However, in contrast to their findings the effect of the

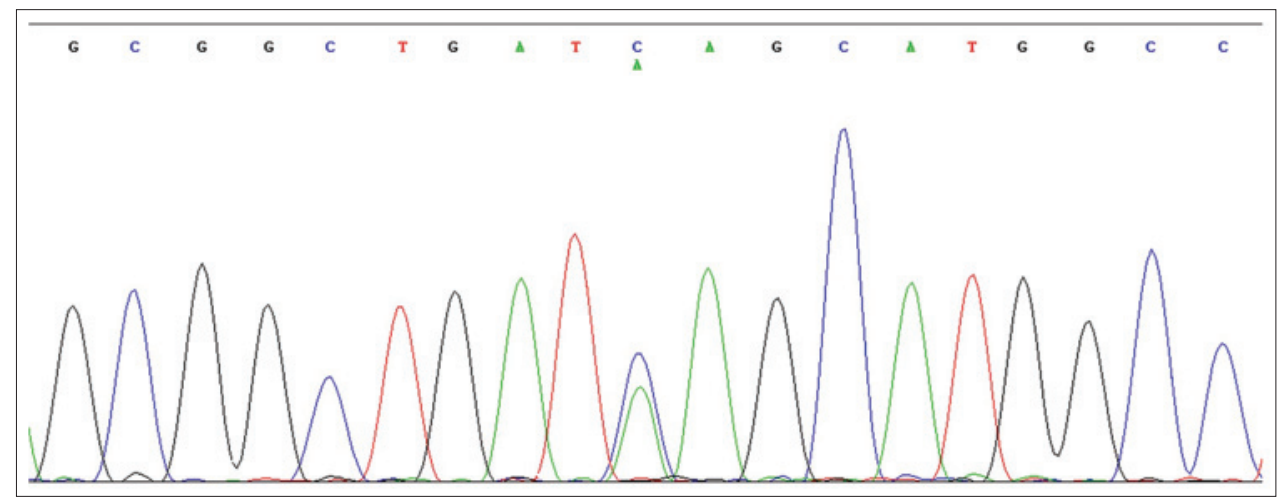

Figure-2: Sequencing chromatogram of heterozygote cattle. 
Table-1: Effect of the genotype at exon 17 of ATP1A1 gene on thermotolerance in cattle.

\begin{tabular}{lcccrr}
\hline Genotype & $\mathbf{R T}_{\mathbf{M}}$ & $\mathbf{R T}_{\mathbf{A}}$ & ART & ARR & HTC \\
\hline Tharparkar & & & & & \\
CC & $38.77^{\mathrm{a}} \pm 0.03$ & $38.56^{\mathrm{a}} \pm 0.03$ & $38.26^{\mathrm{a}} \pm 0.04$ & $15.62^{\mathrm{a}} \pm 0.14$ & $97.82^{\mathrm{a}} \pm 0.33$ \\
CA & $38.88^{\mathrm{b}} \pm 0.03$ & $38.65^{\mathrm{b}} \pm 0.02$ & $38.42^{\mathrm{b}} \pm 0.03$ & $15.98^{\mathrm{a}} \pm 0.12$ & $96.47^{\mathrm{b}} \pm 0.29$ \\
AA & $38.93^{\mathrm{b}} \pm 0.03$ & $38.71^{\mathrm{b}} \pm 0.03$ & $38.48^{\mathrm{b}} \pm 0.03$ & $16.05^{\mathrm{a}} \pm 0.14$ & $95.91^{\mathrm{b}} \pm 0.32$ \\
Vrindavani & & & & & \\
CC & $38.25^{\mathrm{a}} \pm 0.02$ & $38.70^{\mathrm{a}} \pm 0.02$ & $38.48^{\mathrm{a}} \pm 0.02$ & $15.56^{\mathrm{a}} \pm 0.09$ & $98.23^{\mathrm{a}} \pm 0.19$ \\
CA & $38.34^{\mathrm{b}} \pm 0.02$ & $38.82^{\mathrm{b}} \pm 0.02$ & $38.58^{\mathrm{b}} \pm 0.02$ & $16.12^{\mathrm{b}} \pm 0.07$ & $97.18^{\mathrm{b}} \pm 0.15$ \\
AA & $38.34^{\mathrm{b}} \pm 0.02$ & $38.82^{\mathrm{b}} \pm 0.02$ & $38.58^{\mathrm{b}} \pm 0.02$ & $15.98^{\mathrm{b}} \pm 0.10$ & $97.23^{\mathrm{b}} \pm 0.21$ \\
\hline
\end{tabular}

Different superscript in same column indicate significant differences $(p \leq 0.01), R T_{M}=$ Rectal temperature at 10 am, $\mathrm{RT}_{\mathrm{A}}=$ Rectal temperature at $2 \mathrm{pm}, \mathrm{ART}=$ Average rectal temperature, ARR=Average respiration rate, $\mathrm{HTC}=\mathrm{Heat}$ tolerance coefficient

Table-2: Effect of season on thermotolerance in cattle.

\begin{tabular}{lccccc}
\hline Season & $\mathbf{R T}_{\mathbf{M}}$ & $\mathbf{R T}_{\mathbf{A}}$ & ART & ARR & HTC \\
\hline Tharparkar & & & & & \\
$\quad$ Winter & $38.17^{\mathrm{a}} \pm 0.03$ & $38.61^{\mathrm{a}} \pm 0.03$ & $38.39^{\mathrm{a}} \pm 0.03$ & $14.86^{\mathrm{a}} \pm 0.14$ & $99.11^{\mathrm{a}} \pm 0.31$ \\
Spring & $38.37^{\mathrm{b}} \pm 0.03$ & $38.85^{\mathrm{b}} \pm 0.03$ & $38.61^{\mathrm{b}} \pm 0.03$ & $15.51^{\mathrm{b}} \pm 0.14$ & $96.90^{\mathrm{b}} \pm 0.31$ \\
$\quad$ Summer & $38.63^{\mathrm{c}} \pm 0.03$ & $39.13^{\mathrm{c}} \pm 0.03$ & $38.88^{\mathrm{c}} \pm 0.03$ & $17.28^{\mathrm{c}} \pm 0.14$ & $94.19^{\mathrm{c}} \pm 0.31$ \\
Vrindavani & & & & & \\
Winter & $37.93^{\mathrm{a}} \pm 0.02$ & $38.46^{\mathrm{a}} \pm 0.02$ & $38.20^{\mathrm{a}} \pm 0.02$ & $14.02^{\mathrm{a}} \pm 0.08$ & $101.01^{\mathrm{a}} \pm 0.18$ \\
Spring & $38.30^{\mathrm{b}} \pm 0.02$ & $38.73^{\mathrm{b}} \pm 0.02$ & $38.50^{\mathrm{b}} \pm 0.02$ & $15.22^{\mathrm{b}} \pm 0.08$ & $97.89^{\mathrm{b}} \pm 0.18$ \\
Summer & $38.70^{\mathrm{c}} \pm 0.02$ & $39.15^{\mathrm{c}} \pm 0.02$ & $38.93^{\mathrm{c}} \pm 0.02$ & $18.43^{\mathrm{c}} \pm 0.08$ & $93.74^{\mathrm{c}} \pm 0.18$ \\
\hline
\end{tabular}

Different superscript in same column indicate significant differences $(p \leq 0.01), R T_{M}=$ Rectal temperature at 10 am; $\mathrm{RT}_{\mathrm{A}}=$ Rectal temperature at $2 \mathrm{pm}, \mathrm{ART}$, Average rectal temperature, ARR=Average respiration rate; HTC=Heat tolerance coefficient

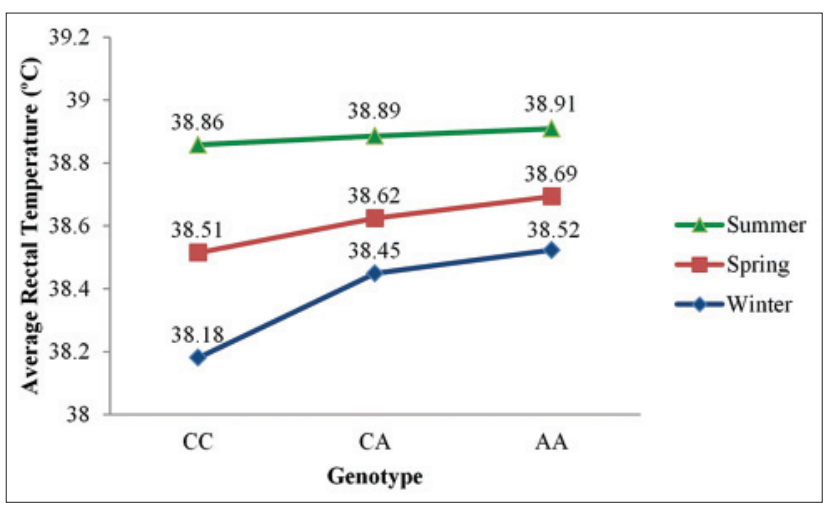

Figure-3: Average rectal temperature of different genotypes in Tharparkar.

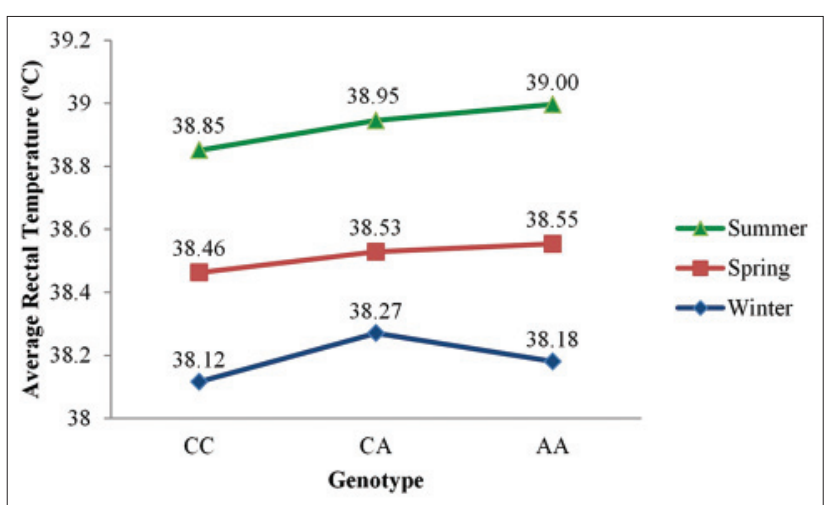

Figure-4: Average rectal temperature of different genotypes in Vrindavani.

genotype in this study was not restricted to heat tolerance; rather it was contributing to thermal balance in all seasons.

\section{Conclusions}

There are certain genes, controlling response to heat stress either by altering heat production and heat loss balance or by exerting cytoprotective actions. One of those genes conferring heat tolerance is ATP1A1, encoding for the $\alpha 1$ chain of $\mathrm{Na}^{+} / \mathrm{K}^{+}$-ATPase. The effects of genotypes for exon 17 of ATP1A1 showed significant association with heat tolerance parameters. Genotype CC had a significantly $(\mathrm{p} \leq 0.01)$ lower HTC value, RT, and RR in both Tharparkar and Vrindavani, marking it as more efficiently thermoregulated genotype. Furthermore, genotype $\mathrm{CC}$ was associated with not only lower RT and RR in summer, but in all seasons, suggesting that genotype CC confers to overall low thermal balance, that is extended to be favorable in terms of heat tolerability in summer.

\section{Authors' Contributions}

NK: Research was done by this author as the part of his master's degree thesis dissertation. PK: Designed the study and supervised the research as major advisor of NK. BD: Worked and collaborated in the standardization of protocols and compilation of the results reported in the manuscript as well as compilation of the manuscript. SB: Collaborated in the lab work and shared a lot of opinions regarding the work. AK and AC: Provided valuable suggestions regarding the design of the experiment and analysis of the data collected during research. BB: As a member of advisory committee, contributed in all aspects of the work and shared lab facilities to facilitate experiments. GS: As an expert of animal physiology 
and climatology, provided valuable suggestions and implementable ideas of recording physiological and climatological parameters. DS: Provided valuable suggestions regarding the conduct of the experiment and necessary timely support needed to complete the work. All authors read and approved the final manuscript.

\section{Acknowledgments}

The authors are thankful to the Director of the Institute and in-charge of cattle and buffalo farm of the Institute for providing all necessary facilities and support during the study. The work was funded by IVRI internal funds to facilitate the masters' research of the first author.

\section{Competing Interests} interests.

The authors declare that they have no competing

\section{References}

1. Tao, S., Monteiro, A.P., Thompson, I.M., Hayen, M.J. and Dahl, G.E. (2012) Effect of late-gestation maternal heat stress on growth and immune function of dairy calves. $J$. Dairy Sci., 95(12): 7128-7136.

2. Kamiya, M., Kamiya, Y., Tanaka, M. and Shioya, S. (2006) Milk protein production and plasma 3-methylhistidine concentration in lactating holstein cows exposed to high ambient temperatures. Asian-Aust. J. Anim. Sci., 19(8): 1159.

3. Boonkum, W., Misztal, I., Duangjinda, M., Pattarajinda, V., Tumwasorn, S. and Sanpote, J. (2011) Genetic effects of heat stress on milk yield of Thai Holstein crossbreds. $J$. Dairy Sci., 94(1): 487-492.

4. Herbut, P. and Angrecka, S. (2012) Forming of temperature-humidity index (THI) and milk production of cows in the free-stall barn during the period of summer heat. Anim. Sci. Pap. Rep., 30(4): 363-372.

5. Gantner, V., Mijić, P., Kuterovac, K., Solić, D. and Gantner, R. (2011) Temperature-humidity index values and their significance on the daily production of dairy cattle. Mljekarstvo, 61(1): 56-63.

6. Ghavi Hossein-Zadeh, N., Mohit, A. and Azad, N. (2013) Effect of temperature-humidity index on productive and reproductive performances of Iranian Holstein cows. Iran. J. Vet. Res., 14(2): 106-112.

7. Pongpiachan, P., Rodtian, P. and Ota, K. (2003) Effects of tropical climate on reproduction of cross-and purebred Friesian cattle in northern Thailand. Asian-Aust. J. Anim. Sci., 16(7): 952-961.

8. Krininger $3^{\text {rd }}$, C.E., Stephens, S.H. and Hansen, P.J. (2002) Developmental changes in inhibitory effects of arsenic and heat shock on growth of pre-implantation bovine embryos. Mol. Reprod. Dev., 63(3): 335-340.

9. El-Wishy, A.B. (2013) Fertility of holstein cattle in a subtropical climate of egypt. Iran. J. Appl. Anim. Sci., 3(1): 45-51.

10. Mellado, M., Romero, P., García, J., Véliz, F. and Arévalo, J. (2010) The effects of ambient temperature and humidity on pregnancy rate in Beefmaster cows in a subtropical environment of Mexico. Livest. Sci., 131(2): 149-154.

11. Sonna, L.A., Fujita, J., Gaffin, S.L. and Lilly, C.M. (2002) Invited review: effects of heat and cold stress on mammalian gene expression. J. Appl. Physiol., 92(4): 1725-1742.

12. Olson, T.A., Lucena, C., Chase, C.C. and Hammond, A.C. (2003) Evidence of a major gene influencing hair length and heat tolerance in Bos taurus cattle. J. Anim. Sci., 81(1): 80-90.

13. Wang, Z., Wang, G., Huang, J., Li, Q., Wang, C. and
Zhong, J. (2011) Novel SNPs in the ATP1B2 gene and their associations with milk yield, milk composition and heat-resistance traits in Chinese Holstein cows. Mol. Biol. Rep., 38(3): 1749-1755.

14. Li, Q., Han, J., Du, F., Ju, Z., Huang, J., Wang, J., Li, R., Wang, C. and Zhong, J. (2011) Novel SNPs in HSP70A1A gene and the association of polymorphisms with thermo tolerance traits and tissue specific expression in Chinese Holstein cattle. Mol. Biol. Rep., 38(4): 2657-2663.

15. Bhat, S. (2012) Molecular characterization of HSP70A1A gene and its association with heat tolerance in cattle. Division of Animal Genetics MVSc, Indian Veterinary Research Institute, Izatnagar, Bareilly, India.

16. Charoensook, R., Gatphayak, K., Sharifi, A.R., Chaisongkram, C., Brenig, B. and Knorr, C. (2012) Polymorphisms in the bovine HSP90AB1 gene are associated with heat tolerance in Thai indigenous cattle. Trop. Anim. Health Prod., 44(4): 921-928.

17. Vague, P., Dufayet, D., Coste, T., Moriscot, C., Jannot, M. F. and Raccah, D. (1997) Association of diabetic neuropathy with $\mathrm{Na} / \mathrm{K}$ ATPase gene polymorphism. Diabetologia, 40(5): 506-511.

18. Xu, K.Y. (2005) Activation of $\left(\mathrm{Na}^{+} / \mathrm{K}^{+}\right)$-ATPase. Biochem. Biophys. Res. Commun., 338(4): 1669-1677.

19. Dostanic-Larson, I., Lorenz, J.N., Van Huysse, J.W., Neumann, J.C., Moseley, A.E. and Lingrel, J.B. (2006) Physiological role of the $\alpha 1$-and $\alpha 2$-isoforms of the $\mathrm{Na}^{+}-$ $\mathrm{K}^{+}$-ATPase and biological significance of their cardiac glycoside binding site. Am. J. Physiol. Regul. Integr. Comp. Physiol., 290(3): R524-R528.

20. Choi, C.Y. and An, K.W. (2008) Cloning and expression of $\mathrm{Na}^{+} / \mathrm{K}^{+}$-ATPase and osmotic stress transcription factor 1 mRNA in black porgy, Acanthopagrus schlegeli during osmotic stress. Comp. Biochem. Physiol. (B) Biochem. Mol. Biol., 149(1): 91-100.

21. Zicha, J., Negrin, C.D., Dobešová, Z., Carr, F., Vokurková, M., Mcbride, M.W., Kuneš, J. and Dominiczak, A.F. (2001) Altered $\mathrm{Na}^{+}-\mathrm{K}^{+}$pump activity and plasma lipids in salt-hypertensive Dahl rats: relationship to ATP1Al gene. Physiol. Genomics, 6(2): 99-104.

22. Barendse, W., Reverter, A., Bunch, R.J., Harrison, B.E., Barris, W. and Thomas, M.B. (2007) A validated whole-genome association study of efficient food conversion in cattle. Genetics, 176(3): 1893-1905.

23. Glorioso, N., Herrera, V.L.M., Bagamasbad, P., Filigheddu, F., Troffa, C., Argiolas, G., Bulla, E., Decano, J.L. and Ruiz-Opazo, N. (2007) Association of ATP1A1 and dear single-nucleotide polymorphism haplotypes with essential hypertension sex-specific and haplotype-specific effects. Circ. Res., 100(10): 1522-1529.

24. Yang, S. (2007) Study on seasonal variation on some biochemical indices of blood and correlation between them and heat tolerance in holstein cows. Xinjiang Agriculture University, Ürümqi, Xinjiang. p287-335.

25. Liu, Y.X., Zhou, X., Li, D.Q., Cui, Q.W. and Wang, G.L. (2010) Association of ATP1A1 gene polymorphism with heat tolerance traits in dairy cattle. Gen. Mol. Res., 9(2): 891-896.

26. Liu, Y.X., Li, D.Q., Li, H.X., Zhou, X. and Wang, G.L. (2011) A novel SNP of the ATP1A1 gene is associated with heat tolerance traits in dairy cows. Mol. Biol. Rep., 38(1): 83-88.

27. Wang, G., Kawakami, K. and Gick, G. (2007) Divergent signaling pathways mediate induction of $\mathrm{Na}, \mathrm{K}$-ATPase $\alpha 1$ and $\beta 1$ subunit gene transcription by low potassium. Mol. Cell. Biochem., 294(1-2): 73-85.

28. Das, R., Gupta, I., Verma, A., Singh, A., Chaudhari, M.V., Sailo, L., Upadhyay, R. and Goswami, J. (2015) Genetic polymorphisms in ATP1A1 gene and their association with heat tolerance in Jersey crossbred cows. Indian J. Dairy Sci., 68: 1.

29. Kashyap, N., Kumar, P., Deshmukh, B., Dige, M.S., 
Sarkar, M., Kumar, A., Chauhan, A. and Singh, G. (2014) Influence of ambient temperature and humidity on ATP I Al gene expression in Tharparkar and Vrindavani cattle. Indian J. Anim. Res., 48(6): 541-544.

30. Finch, V.A. (1986) Body temperature in beef cattle: Its control and relevance to production in the tropics. J. Anim. Sci., 62(2): 531-542.

31. Hammond, A.C., Olson, T.A., Chase, C.C., Bowers, E., Randel, R.D., Murphy, C.N., Vogt, D.W. and Tewolde, A. (1996) Heat tolerance in two tropically adapted bos taurus breeds, senepol and romosinuano, compared with brahman, angus, and hereford cattle in Florida. J. Anim. Sci., 74(2): 295-303.

32. Molee, A., Bundasak, B., Kuadsantiat, P. and Mernkrathoke, P. (2011) Suitable percentage of Holstein in crossbred dairy cattle in climate change situation. J. Anim. Vet. Adv., 10(7): 828-831.

33. Sambrook, J. and Russell, D.W. (2001) Molecular Cloning: A Laboratory Manual. Cold Spring Harbor, NY, USA.

34. Bassam, B.J., Caetano-Anollés, G. and Gresshoff, P.M. (1991) Fast and sensitive silver staining of DNA in polyacrylamide gels. Anal. Biochem., 196(1): 80-83.

35. McDowell, R.E., Hooven, N.W. and Camoens, J.K. (1976) Effect of climate on performance of Holsteins in first lactation. J. Dairy Sci., 59(5): 965-971.

36. Rhoad, A.O. (1944) The Iberia heat tolerance test for cattle. Trop. Agric., 21(9): 162-164.

37. Ravagnolo, O., Misztal, I. and Hoogenboom, G. (2000) Genetic component of heat stress in dairy cattle, development of heat index function. J. Dairy Sci., 83(9): 2120-2125. 